\title{
Formal instruction by Song for English Learners in SMP IT Darul Hasan while Pandemic Era
}

\author{
Fatma Muhriza \\ Universitas Negeri Padang \\ email: fatmamuhriza05@gmail.com
}

\begin{abstract}
This research was examined to help the English teacher in Junior high school especially, while pandemic Covid-19 more dilate over the world. The pandemic that has hit the world in the last 3 years, it gas given much attention from all elements in the world generally, the side of education do need new innovations to keep advancing the target of education, so one of thing teachers do at SMP IT Darul Hasan Kota Padangsidimpuan to overcome the problem have tried carry out formal instruction in achieving good English grammar according to their target and age, namely through songs with grammar elements according to the lesson curriculum in social media flat form. This research have done for treat in 7 class SMP IT Darul Hasan Kota Padangsidimpuan that consist of 25 students randomly. The three classes have a different acquisition in English subject, again which the students in 7d, 7e, and 7f. So, in my conclusion that formal instruction by song in Junior high school SMP IT Darul Hasan Kota Padangsidimpuan has given a positive effect.
\end{abstract}

Keywords: Pandemic, World Education, Education Target, Formal Instruction, Song

\section{Introduction}

Language is an important thing in human life which is also a communication tool in daily activities. According to Wibowo (2001), language is a system of symbols that are meaningful sound that are arbitrary and conventional, which is used as a means of communication by a group of men to give birth to feelings and thoughts. English as an international language is one of the most important languages for humans. With human communication, it will be easier to provide information, carry out a job, or realize ideas.

The COVID-19 pandemic outbreak spread outside the city of Wuhan on January 30, 2020. This outbreak has spread to all parts of the world and currently more than 248,000,000 people are affected and 5,02 more have passed away. People are not allowed to leave their homes, work or even go to school because of this outbreak. For more than 2 years until now, the world has experienced quite powerful in all aspects. Especially in our country, Indonesia, many aspects are quite worrying, which are the economy, politics, religion, education, and so on. So here I am going to focus on education This confusion also has an impact on teaching and learning at SMP IT Darul Hasan Kota Padangsidimpuan.

In order to provide education during a pandemic, our government has set an emergency law that requires the government to close face-to-face learning. All learning activities are held at home. (Kemendikbud Nomor 719_P_2020) and also the curriculum and syllabus have been set to be smaller, so it does not have to be $100 \%$ as in normal time (Penyesuaian Kebijakan Pembelajaran di Masa Pandemic). COVID-19 (2020)

However, the curriculum and learning process have changed drastically. In language learning, the teacher needs to be more creative and innovative in designing a lesson to make the learners achieve the 
targets. Learning English at junior high school level is very interesting to study, and researchers will conduct research on learning English at SMP IT Darul Hasan Kota Padangsidimpuan.

SMP IT Darul Hasan is one school in Padangsidimpuan City in North Sumatera that has applied lesson instruction in English subjects especially. In language learning, teachers provide fun and exciting media instructions. At this school, language teachers have to make songs for English class and send them by WhatsApp group. There are quite a lot of channels as well as a reference for teachers such as:

1. Teaching grammar to young learners in a real-world context: $t=2122 \mathrm{~s}$ https://www.youtube.com/watch?v=-CM5m0WG6AU

2. Using songs to teach English to young learners: www.youtube.com/watch?v=kA1FuDdtq54

3. Tips for teaching grammar to young learners: www.youtube.com/watch? $\mathrm{v}=\mathrm{kgJNYIc8DHo}$

Why do we choose a song? My point is, teachers need to modify the lesson for fun. There is no pressure, no stress, or force mentality. But there are still some targets we need. We hope students can grasp the grammatical features in the target language and the positive effect of focusing on form within a communicative context, such as songs in videos on social media platforms. Even though there is no classroom anymore. It was also found in a Canadian study of the acquisition of several English structures by 10-12-year-old francophone students in an intensive ESL course (Spada and Lightbown 1993). Of course, this needs time to prepare and time. In SMP IT, Darul Hasan, the English teacher, does it together. Here some lyrics have been shared which can be opened:

1. Apple Music: https://music.apple.com/us/album/the-greetings-song/1073829913?i=1073829914

2. https://music.apple.com/us/album/your-name/1073829913?i=1073829915

3. Apple Music: https://music.apple.com/us/album/alphabet-sounds/1073829913?i=1073829916

4. Apple Music: https://music.apple.com/us/album/the-color-song/1073829913?i=1073829917

5. https://music.apple.com/us/album/h-a-p-p-y/1073829913?i=1073829929

As such the lyrics to the song below help students not just learn the lyrics, but some grammar aspects as well, which we can explain a bit.

Five Little Ducks

Five little ducks went out one day,

Over the hills and far away.

Mother duck said, "quack quack quack

quack,"

But only four little ducks came back.

Four little ducks went out one day, Over the hills and far away.

Mother duck said, "quack quack quack quack,"

But only three little ducks came back.

Three little ducks went out one day,

Over the hills and far away.

Mother duck said, "quack quack quack quack,"

But only two little ducks came back.

Two little ducks went out one day,

Over the hills and far away.

Mother duck said, "quack quack quack quack,"

But only one little duck came back.

One little duck went out one day,

Over the hills and far away.

Mother duck said, "quack quack quack quack," 
But none of the five little ducks came back.

So sad Mother duck went out one day,

Over the hills and far away.

Mother duck said, "quack quack quack quack,"

And all of the five little ducks came back

From the lyrics, students can get some formal instruction form like articles, adjectives, and descriptive that teacher can explain after singing and practice for more time to understand it.

A study of a similar student sample in a similar learning environment revealed that flooding learners for 2 weeks with specially prepared materials on adverb placement in English without any form-focused instruction was not sufficient to drive out forms that are permitted in French but not in English from the students'(Kira, 2020). Even if so many resources can be a resource in the lessons, The resources are grouped into three broad sections, according to our purpose (Reimers, Schleicher, Saavedra, \& Tuominen, 2020)

1. Curriculum Resources: These include lessons, videos, interactive learning modules, and any other resources that directly support students in acquiring knowledge and skills.

2. Professional Development Resources: These are resources that can support teachers or parents in supporting learners, guiding them to content, developing their skills to teach remotely, or more generally augmenting their capacity to support learners now learning more independently and at home, rather than at school.

3. Tools: These include tools that can help manage teaching and learning, such as communication tools, learning management systems, or other tools that teachers, parents, or students can use to create or access educational content.Hung was quoted as saying:

I never taught any grammars. I guess I just never learned the rules that well. I know that every time I speak it's pretty correct, so I never think about grammars. I just write down whatever I feel like it. Everytime I write something I just stop thinking. I don't know which (rule) to apply...(p.59).

In these studies, two sorts of linguistic environments are contrasted: artificial, or formal environments, found for the most part in the classroom, and natural or informal environments students can more relax by song at that time they are studied as well. Krashen and Seliger (1975) have noted that all language teaching systems are utilized for the adult-use activities in which linguistic rules are presented one at a time and in which some sort of feedback (error correction and/or error detection) is present. Other features of formal instruction (e.g. deductive presentation of rules ) are not common to all teaching methods. Krashen and Seliger also note that these features (rule isolation and feedback) do not seem to be present in informal environments.

Formal instruction is in the different conditions and makes them can still relax and have no treasure. So by another resource here how about students learn by music in this class that is have sent by the teacher in WhaatsAap or others.

Contributions of Formal and Informal Environments It is not simply the case that informal environments provide the necessary input for acquisition while the classroom aids in increasing learned competence. Krashen et al. series as well as the Friedlander et al. data described above suggest, first of all, that informal environments must be intensive and involve the learner directly to be effective. One might then distinguish "exposure-type" informal environments and "intake-type" environments. Only the latter provide true input to the language acquisition device. Second, it seems plausible that the classroom can accomplish both learning and acquisition simultaneously. While classwork is directly aimed at increasing conscious linguistic knowledge of the target language, to the extent that the target language is used realistically, to that extent will acquisition occur. In other words, the classroom may serve as an "intake" informal environment as well as a formal linguistic environment. Also as governments need to 
innovate the program education as well, many government over the world held the conference to solve this problem, they are implementing measures that limit the number of people congregating public because the duration of such measures has been extensive, leader leader of puplic private education institutions have put in place alternative method for students and teacher continue with their lessons for working in safe environment. (Fernando Reimers, Andreas Schleicher, Jaime Saavedra, Saku Tuominen: 2020)

\section{Methods}

This study was done in 2 week. 12-25 October 2021 in SMP IT Darul Hasan Kota padangsidimpuan north Sumatera. the address is Jl. Ompu Huta Tunjul, Kelurahan Hutaimabaru, Kec. Paangsidimpuan Hutaimabaru. As the main purpose of the study was to know and analyze how songs can still make students get the target curriculum in grammar while pandemic era. The method used in this research is qualitative research with the type of phenomenological research. According to Polkinghorne (in Creswell, 1998) Phenomenological studies illustrate the meaning of a life experience for some people about a concept or phenomenon.

The research subjects are the English teacher who teaches at SMP IT Darul Hasan Kota Padangsidimpuan. The researcher interview one English teacher at SMP IT Darul Hasan Kota Padangsidimpuan and 25 students in seven classes. The researcher chose one research subject because the teacher is a key informant who has met the requirements as a key informant. And I chose 25 students randomly from the 3 classes based on the teacher recommendation. According to (Martha \& Kresno, 2016) there are four criteria in determining key informants:

1. Must be an active participant in the group, organization, or culture being researched.

2. Must be involved in the "current" researched culture.

3. Have adequate time.

4. Convey information in their language (natural) In addition, statements from respondents were also supported and clarified by statements by several students at SMP IT Darul Hasan Kota Padangsidimpuan.

The data were collected from a two-part questionnaire, interview, and documentation. In the first questionnaire, we formulated open-ended questions on student knowledge grammar ( in appendix 1), the students were also provided with 2 situations, one situation by lecturing and explaining the matter and another condition by song firstly. the second part questionnaire practice-oriented student knowledge grammar by song (Appendix 2). Include the sentences in and modify them to other sentences.

After the questionnaire which was filled in anonymously y the students, 25 individual interviews were conducted with the research participant to collect more in-depth information. The interview and questionnaire had the same procedure. In the first part interview, the participant answers the question by their background knowledge. In the second part of the interview, they were provided with the 2 lyric texts. The answers of the students in the first and second parts of the interview were compared for discrepancies. The open-ended part of the questionnaires and the transcribed interviews were coded and related to the theme.

In this study, qualitative rather than quantitative methods were employed as the aim of the study was to students' experiences concerning songs and express them by other sentences in the same grammar zone. An analysis of the qualitative research, data gathered through the open-ended questionnaires, semi structures interviews, and think-aloud protocol according to the data analysis spiral (Creswell 2007). Here the students had many different perceptions to apply the grammar in real life, but after by using the song it made them easy understand, no stress and pressures. 


\section{Results and Discussion}

All of the data were gotten from English teachers and 25 at SMP IT Darul Hasan Kota Padangsidimpuan. The researcher presents the results of the interviews, questionnaires, and documentation that have been examined. Students' perceptions of songs were analyzed in terms of their definitions. Get knowledge and show the grammar zone in the text (song liryc). One student, for instance, applies the song in daily chats with her friend in the whatsAap group. It made other students applaud as well. 21 student members in this group can apply those utterances like pronouns and certain nouns.

It was revealed that 10 students know well the grammar, but after the teacher share the song and explain about the grammar contains in the song students know well until 21 peoplen. On the other side learning in formal instruction by a song, it made students more convenient, no stress, and easy to remember the grammar zone from the sentences in the lyric of songs. Also, in the second questionnaire, 10 students can apply it for other sentences and use it in the short chatting conversation by the WhatsApp group. After I ask them, they were really happy to sing the song even though it was just in daring class.

The 25 students' perceptions were that they were very happy, motivated, and enthusiastic about learning online. After the third song that has been shared, students can underline and determine the grammar zone based on the matter. The special thing was they can chat by imitating the word from the song for example "I made it" we look at them" join us" and so on.

Below are some of the results obtained by researchers from interviews with English teachers at SMP IT, Darul Hasan Kota, Padangsidimpuan. It is regarding English language teaching activities during the COVID-19 pandemic. Formal instruction in the form of a song in web or social media.

"Learning during the COVID-19 pandemic has significant changes, especially in the learning system. Learning that initially took place conventionally or face-to-face turned into online learning. Based on the results of interviews with respondents, the respondents gave the following statements about learning during the pandemic."

"The learning system has changed greatly. Initially, the teacher explained face-to-face and the children could immediately understand and follow. If there were questions, students could ask directly and the teacher answered immediately. The final results or assessments also changed. Results must be changed and processed using online report cards. For daily tests, students usually use paper. Now students have to use media to work on questions. The media is their cell phones. "

Based on the data above, researchers can find out the teacher's opinion about English teaching activities during the pandemic era as a result of various changes in the learning system.

Song in formal instruction was used to teach English during the pandemic. The teacher provides certain songs that relate to the learning material and are used by students in learning. Then the song is explained by using a voice message. Based on the results of interviews with respondents, the respondents gave the following statements: I share and I turn the song related to the matter, after which I summarize the learning material that I wrote on a paper, and then I explain the summary to the students using voice notes, and then I share them through WhatsApp groups."

Based on the data above, the teacher used songs in teaching English activities. The song was prepared based on the matter, and a summary of the material was explained using voice notes and shared through the WhatsApp group.

The following are examples are the results of interviews with respondents:

"The facilities in teaching English, I make a summary of the material that I note and then I photograph. I also use Google Forms when testing. Then, the assignment is collected in two ways: first by taking a photo of the assignment and sending it to the group, and second, by having students collect it themselves and bring it to school. The task has two functions, for assessment and as an absence." The facilities used by the teacher when teaching English during the pandemic were using a summary of the material that had been made by the teacher and using the Google form during tests. The task given by the teacher to students has two functions, namely for assessment and as an absence. 
Regarding the response of students in formal instruction, the song "Allah makes everything" had a positive effect on learning motivation. Table 1. students reported motivation and respond in learning by song from the song by title Allah make everything.

Table 1. Students' Response

\begin{tabular}{cc}
\hline Song & Responses \\
\hline Allah makes everything & Happy $(1,5,7,8,10,14,20)$ \\
& Very happy $(2,15,16,17,18,19)$ \\
& Happy $(6,11,12)$ \\
& Motivated $(3,9,13,22,23,24,25)$ \\
\hline
\end{tabular}

As can be seen in Figure 1 below, participant held the knowledge in grammar zone from the song.

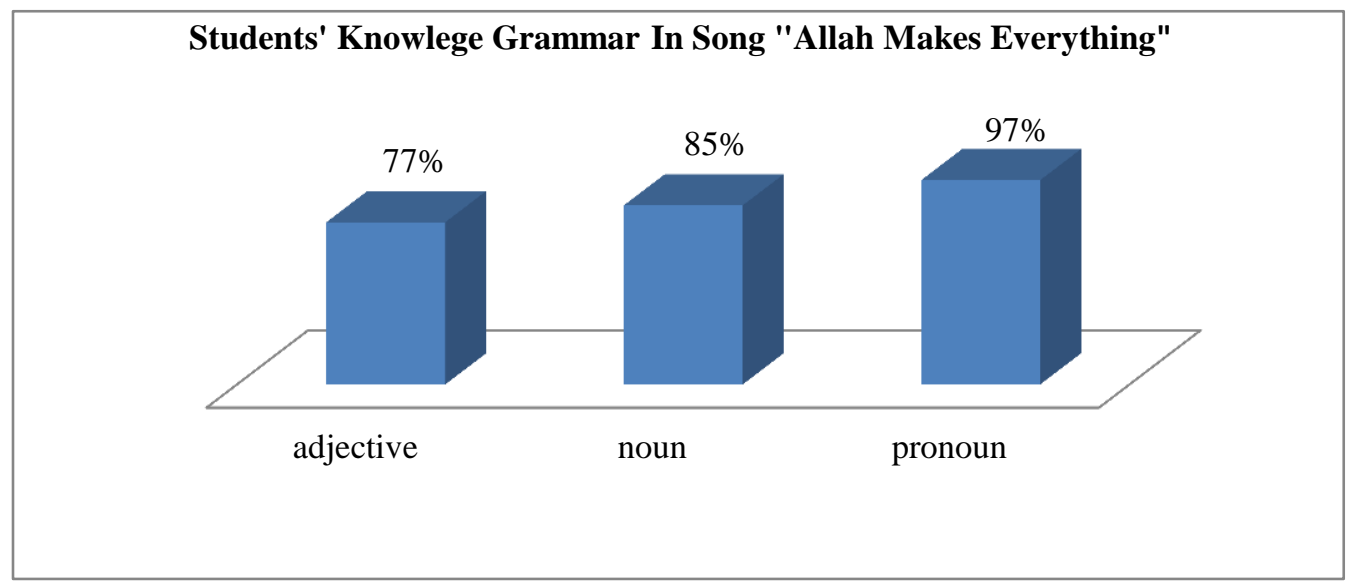

Figure 1. Students' knowledge grammar after learning by song

The most frequently repeated strategies offered y the participant is raising the knowledge in pronoun. Fortunately, The acquisition-learning distinction, student will get 2 big aspects that so useful Selinker propose that for rule internalization one can "postulate two distinct types of cognitive structures (Stephen D Krashen:2002):

1. Those mechanisms that guide 'automatic' language performance... that is, performance... where speed and spontaneity are crucial and the learner has no time to consciously apply linguistic mechanisms... by the listening the teacher sing the lyric make them easy to consume it.

2. Those mechanisms that guide puzzle- or problem-solving 2 performance..." (p.35). Corder (1967), citing an unpublished paper by Lambert, also discusses the acquisition-learning distinction and the possibility that acquisition is available to the adult second language performer.

Below is a small chart how communication gives effect indirect version for students.

Learned system

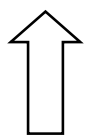

Acquired system Utterance

Figure 2. Model how second language performance 
In Figure 1 is effect the table 1 and table 2, acquire system and learned system become utterance, which mean in Table 1 the song as a learning system gave student high motivation and took them easy understand the instruction from the song.

The teaching and learning activities that occurred during the COVID-19 pandemic has brought some changes to students, teachers, and also parents. Learning that initially took place offline (face-to-face) became completely online. The existence of high teaching motivation by the teacher can also increase learning motivation for students. This statement is in line with the opinion of Patrick et.al. (2000), he said that teacher enthusiasm is directed to achieve high teacher performance.

Learning is done using the internet so as to allow teachers and students to be in different during the learning process. According to Bell et al., (2017) learning carried out using internet technology allows for interaction via the web, where teachers and student are in the right place separately. Learning from home is a good way to reduce the spread of Covid-19 in the school environment. Most people, at one time or another, have experienced learning a language through formal instruction. It may been a compulsory subject a school, a local language class to prepare the knowledge. Or even private classes with a personal tutor.

Teaching and learning activities that occurred during the COVID-19 pandemic has brought some changes to students, teachers, and also parents. Learning that initially took place offline (face-to-face) became completely online. Changes in the learning system during the pandemic had an impact on the learning activities of teachers, students and parents. The existence of high teaching motivation by the teacher can also increase learning motivation for students. This statement is in line with the opinion of Patrick et.al. (2000), he said that teacher enthusiasm is directed to achieve high teacher performance.

\section{Conclusion}

English teaching and learning activities during the COVID-19 pandemic have several changes. The changes are in the learning system, which initially ran conventionally (face to face) to online learning. Learning administration must also be changed to be completely online, for example using audio, video, YouTube, and Google forms. The final report (report card) has also changed, from a book report to an online report card.Formal instruction can be done by many ways, so many method has be done by researcher and teacher as well. In SMP IT Darul Hasan Padangsidimpuan city has applied the fun learning by learning by the song, the song that perform in the video learning. the grammar target still get catch up well.

The method used by teachers when teaching English during the COVID-19 were formal instruction by song. The teacher prepared out a song in the form of a song and students would then give the matter that is contained in the song orally and sent to the whatsApp group. Teacher also used task-based learning method to know the improvement and increase the students' grammar knowledge by the song.

The facilities used by teachers in teaching and learning activities during the COVID-19 pandemic are by using the WhatsApp application. The teacher provides material in the form of audio, images, and videos to students. In addition, and from the interview, questionnaire and documentation showed the positive effect. the students' perception of learning by song are so different after using song. The students get the points' grammar from the songs based on the target curriculum. And the last There are difference in students' grammar knowledge by song.

\section{References}

Gor, K., \& Chernigovskaya, T. (2005). Formal instruction and the acquisitionof verbal morphology. pp $103-136$. 
Graham, R. C. (2004). Blended learning systems: Definition, current trends, and future directions. An Imprint of Wiley.

Khalil, Rehana, et.al. 2020. The Sudden Transition to Synchronized Online Learning During the COVID19 Pandemic in Saudi Arabia: A Qualitative Study Exploring Medical Students' Perspectives. Qassim University, Unaizah, Saudi Arabia.

Krashe, S. (1981). Second language acquisitionandsecond language. University of Southern California.

Kurikulum darurat, Kurikulum Pandemi 2020 https://www.kemdikbud.go.id/main/blog/2020/08 /kemendikbud-terbitkan kurikulum-darurat-pada-satuan-pendidikan-dalam-kondisi-khusus

Long, M. (1976). Encouraging language acquisition by adults in a formal instructional setting. ELT Documents, 76(3), 14-24.

Martha, E. \& Kresno, S. (2016). Metodologi penelitian kualitatif. Jakarta: Rajawali Press.

Rahayu. (2020). Pembelajaran Online di Tengah Pandemi Covid-19. Indonesian Journal of Educational Science (IJES), 2(2), 81-89.

Reimers, F., Schleicher, A. Saavedra, J. \& Tuominen, S. (2020). Supporting the continuation of teaching and learning during the COVID-19 Pandemic Annotated resources for online learning. OECD

Rose, H. (2020). The routledge handbook of research methods in applied linguistics. New York: Taylor and Francis. 